\title{
Tumbled Stock Market, RMB Devaluation and Financial Reform in China
}

Anthony H. F. Li

\section{(2) OpenEdition}

12 Journals

Electronic version

URL: http://journals.openedition.org/chinaperspectives/6870

DOI: 10.4000/chinaperspectives.6870

ISSN: 1996-4617

Publisher

Centre d'étude français sur la Chine contemporaine

\section{Printed version}

Date of publication: 1 December 2015

Number of pages: 63-68

ISSN: 2070-3449

\section{Electronic reference}

Anthony H. F. Li, «Tumbled Stock Market, RMB Devaluation and Financial Reform in China », China Perspectives [Online], 2015/4 | 2015, Online since 01 January 2017, connection on 15 September 2020 URL : http://journals.openedition.org/chinaperspectives/6870 


\section{CefC News Analysis}

\section{Tumbled Stock Market, RMB}

\section{Devaluation and Financial Reform}

in China

ANTHONY H. F. LI

\section{Introduction}

$\mathrm{T}$ 0 Chinese officials who are in charge of financial reform, the summer of 2015 has been disturbingly eventful. China's stock market has plunged since mid-June after months of sharp rise. In less than three months, the Shanghai Stock Exchange (SSE) Composite Index dropped from 5,166 point on 12 June to 2,927 point on 26 August, representing a 43\% drop in stock value. The RMB devaluation in August took global investors and international trading partners by surprise, causing an unintended disturbance to the global financial markets in the shadow of China's lowerthan-expected economic growth. All this has put China under the spotlight across the globe. While China is already the world's second largest economy, its financial system is relatively less developed and is prone to market volatility. The long quest to internationalise the Chinese currency, the yuan or Renminbi (RMB), remains in progress amidst the financial turmoil in China. The question of the extent to which the Chinese government will allow a greater role for the market in currency reform continues to be the crux of the issue.

\section{Review of financial reform in China}

Before the onset of economic reform, the People's Bank of China (PBOC) was tasked with handling almost all lending related to industrial, commercial, and rural uses. (1) The Chinese currency exchange rate was administratively set by the state and merely acted as a tool for accounting purpose in the area of foreign trade. At that time all the foreign exchange earned from foreign trade had to be sold to the state. (2)

Since the economic reforms, China has gradually opened up its market to the world and loosened its restrictions on foreign investment and trade, attracting a surge of foreign loans and direct foreign investment (FDI). The State Administration of Foreign Exchange (SAFE, guojia waihui guanliju 國 家外匯管理局) was established in 1979 to supervise the national balance of payments. (3) In 1981, the dual exchange rate system was created to handle the conversion of foreign currencies into RMB. The PBOC was also restructured in 1984 to separate it from four state-owned commercial banks, enabling it to focus solely on devising macro-economic monetary policies, and it officially became the central bank of China in 1995. Nowadays the banking system in China remains firmly controlled by the Chinese Communist Party (CCP) and serves as the backbone of the financial sector by distributing most of the loans for business activities. Financing through market capitalisation from the stock market or other financial means in China is comparatively insignificant, ${ }^{(4)}$ although given the sheer size of China's economy, the volume of market capitalisation is already huge if compared with other financial markets.

Over the years, China recorded a longstanding "twin surplus" in both current and capital accounts. The increased volume of FDI and net surplus from foreign trade created an unprecedented amount of foreign reserves in the PBOC. The inflow of foreign currencies intensified when China joined the World Trade Organisation (WTO). As required by the WTO, China has fully opened its current account since its accession. The capital account, however, was only partially opened under the control of the authorities. The persistent national imbalance of payments has made China a target of international criticism, especially from the US. ${ }^{(5)}$ In response, China allowed the yuan to appreciate in value over time. In 1997-2005, the PBOC pegged the RMB to the US dollar. Since July 2005, the yuan's exchange rate was allowed to fluctuate within a trading band in reference to a basket of foreign currencies, and the trading band has been further widened to better reflect its market value since 2007. In May 2015, the International Monetary Fund (IMF) for the first time declared that the yuan was no longer undervalued given its recent value appreciation, ${ }^{(6)}$ although the exchange rate is yet to be determined solely by the market.

1. Jinglian Wu, "China's Economic and Financial Reform," in On Kit Tam (ed.), Financial Reform in China, London, Routledge, 1995, p. 85.

2. State Administration of Foreign Exchange, "Lishi yange" (History), www.safe.gov.cn (accessed on 20 October 2015)

3. Gao Xiao and On Kit Tam, "China's Foreign Exchange System," in On Kit Tam (ed.), Financial Reform in China, op. cit., pp. 144-148.

4. Patrick Hess, "China's Financial System: Past Reforms, Future Ambitions and Current State," in Frank Rövekamp and Hanns Günther Hilpert (eds), Currency Cooperation in East Asia, New York, Springer, 2014, pp. 29-30.

5. "China Rebuts US Claim that the Yuan is Still Significantly Undervalued," South China Morning Post, 29 November 2012, www.scmp.com/business/global-economy/article/1093364/china-rebuts-us-claim-yuan-still-significantly-undervalued (accessed on 13 September 2015).

6. Mark Magnier and William Kazer, "IMF Official Says Chinese Yuan No Longer Undervalued," The Wall Street Journal, 26 May 2015, www.wsj.com/articles/imf-official-says-chinese-yuan-nolonger-undervalued-1432634534 (accessed on 13 September 2015). 
Graph 1 - Financial Market Capitalisation in China (1991-2012)

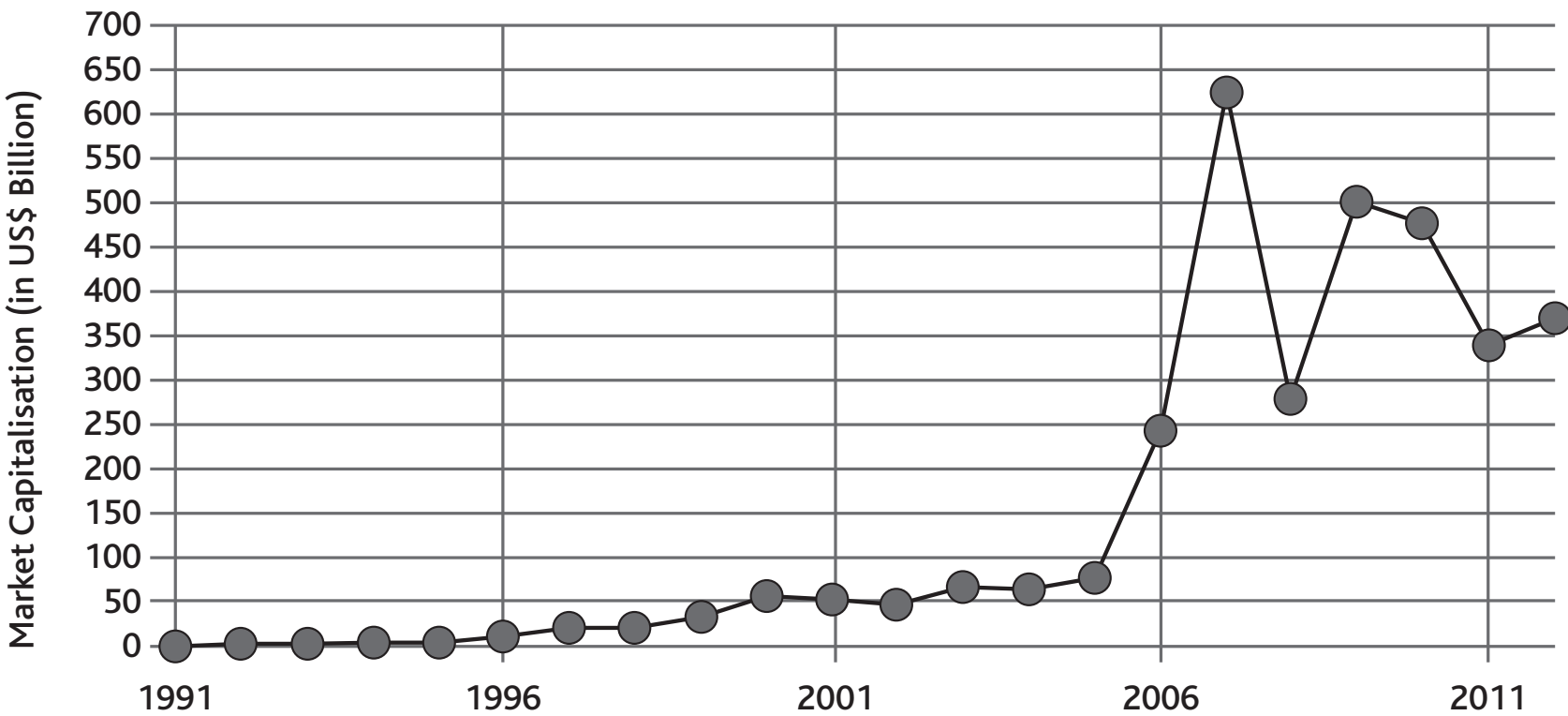

Source:World Bank, "Market capitalization of listed companies (current US\$)," http://data.worldbank.org/indicator/CM.MKT.LCAP.CD (accessed on 21 November 2015).

Integral to the plan to bring in foreign currency was the creation of the stock market. In order to tap foreign capital and improve the financial positions of selected state-owned enterprises (SOEs), stock markets were established in Shanghai and Shenzhen in December 1990 and July 1991 respectively. ${ }^{(7)}$ The state remained the largest shareholder in the SOEs listed on the stock market, and the shares up for sale to non-state parties (i.e. the circulating shares) were limited. To shield the domestic financial market from external shocks, government officials created segmented stock markets that limited the types of buyers and specified trading currencies. The dual financial market system was established with A-shares traded in RMB by Chinese nationals/enterprises only, and B-shares traded in either the US Dollar or Hong Kong Dollar by foreign individual or institutional investors. ${ }^{(8)}$ The segregation of domestic and international markets has persisted to varying degrees until now. Greater integration with the international financial market has been gradually underway with the example of the Shanghai-Hong Kong Stock Connect since November 2014. Market capitalisation through the stock market has increased from US\$0.2 billion in 1991 to US\$369.7 billion in 2012 (see Graph 1). As of May 2015, China's two stock markets combined already ranked second in the world in market capitalisation (US\$14.2 trillion). (9) Yet, unlike other financial markets, China's stock market does not allow genuine valuation of listed companies to be reflected in the traded share prices, because the CCP controls the ownership of the listed companies. ${ }^{10)}$ For the regulation of the financial market, the China Securities Regulatory Committee (CSRC, Zhongguo zhengquan jiandu guanli weiyuanhui 中國證券監督管理委員會) was established in 1992 and later became a national regulatory body under the State Council.

In order to promote the use of the RMB abroad, Chinese policymakers gradually allowed greater cross-border RMB-denominated transactions and opened the capital account. Financial markets, both domestic (onshore) and foreign (offshore), are of great help in this process. Hong Kong, as a Special Administrative Region of China that practices a different set of laws with a well-established financial sector, provides a useful offshore testing ground. A number of steps have been made since 2002, including introduction of the Qualified Foreign Institutional Investors (QFII) programme to allow foreign investors to buy A-shares in 2002, the establishment of an offshore RMB centre in Hong Kong in 2004, etc. In short, the various strategies were to stimulate demand for the RMB in the international market and increase liquidity of the RMB on a global scale. In 2013 , the Third Plenary Session of the $18^{\text {th }}$ CCP Congress re-affirmed China's commitment to a gradual loosening of capital control and allowing a greater role for the market in setting the exchange rate, with the aim of a greater degree of RMB internationalisation. ${ }^{(11)}$ It marked China's pledge to pursue financial reform in the direction of marketisation.

\section{Significant slump in the Chinese stock market in June-July}

In early April 2015, state media encouraged domestic investors to take part in the stock market. Some media reports relayed the perception that the Chinese government would support a bullish market. ${ }^{(12)}$ Subsequently, the number of individual investor registrations reached a record high of 92 million in July. ${ }^{(13)}$ The SSE Composite Index rose $36 \%$ in three months, from 3,810 points on 1 April to 5,166 points on 12 June. When the CSRC realised

7. Barry Naughton, The Chinese Economy: Transitions and Growth, Cambridge, MIT Press, 2006, p. 469.

8. Shu-yun Ma, Shareholding System Reform in China: Privatizing by Groping for Stones, Cheltenham, Edward Elgar, 2010, p. 92.

9. Hong Kong ranked seventh with market capitalisation worth US\$4.0 trillion. See Gregor S. Hunter and Jacky Wong, "Everything You Need to Know About China's Stock Markets," The Wall Street Journal, 10 July 2015, www.wsj.com/articles/everything-you-need-to-know-about-chinas-stockmarkets-1436534913 (accessed on 8 September 2015).

10. Carl E. Walter and Fraser J.T. Bowie, Red Capitalism: The Fragile Financial Foundation of China's Extraordinary Rise (revised and updated), Singapore, Willy, 2012, p. 166.

11. Sara Hsu, "China: New System a Step Forward on RMB Internationalization," The Diplomat, 19 June 2015, http://thediplomat.com/2015/06/china-new-system-a-step-forward-on-rmb-internationalization (accessed on 10 September 2015).

12. "China's Journey from New Normal to Stock Market Crisis Epicenter," Bloomberg, 26 August 2015, www.bloomberg.com/news/articles/2015-08-26/china-s-journey-from-new-normal-to-stockmarket-crisis-epicenter (accessed on 4 September 2015).

13. Peter Spence, "China's Stock Market Crash: Five Numbers You Need to Know," The Telegraph, 31 July 2015, www.telegraph.co.uk/finance/china-business/11772729/Chinas-stock-market-crashfive-numbers-you-need-to-know.html (accessed on 4 September 2015). 
Table 1 - Global Stock Market Rout on 24 August 2015

\begin{tabular}{|l|c|l|}
\hline \multicolumn{1}{|c|}{ Stock Markets } & Index drop on 24 August & Remarks \\
\hline Shanghai, China & $8.5 \%$ & \\
\hline Shenzhen, China & $7.7 \%$ & \\
\hline Hong Kong & $5.2 \%$ & A record one-day drop by 7.5\% in the trading period \\
\hline Taiwan & $4.8 \%$ & \\
\hline Korea & $2.5 \%$ & Biggest one-day drop in more than 2 years \\
\hline Japan & $4.6 \%$ & \\
\hline Australia & $4.4 \%$ & A record one-day drop by 1,000 points at its opening \\
\hline The US & $3.1 \%$ & Largest one day drop in 7 years \\
\hline Pan-European FTSE Eurofirst 300 & $5.4 \%$ & \\
\hline
\end{tabular}

Sources: Bloomberg, Financial Times, South China Morning Post, CNN, Southern Weekly.

the potential for a financial bubble, it attempted to assert greater regulation but unintentionally pushed the stock market over the edge by scaring off profiteers. In mid-June, the Shanghai A-shares stock market went into a sudden slump, from 5, 166 points on 12 June to 3,507 points on 8 July (the lowest point before the RMB devaluation), representing a $32 \%$ drop within a month. To prevent the crash from worsening, policymakers solicited help from state-owned financial agencies dubbed the "National Team," of which the China Securities Finance Corporation (CSFC, Zhongguo zhengquan jinrong gufen youxian gongsi 中國證券金融股份有限公司) has been a major player since late June. ${ }^{(14)}$ In the midst of the market crash, the regulatory body CSRC, as financially supported by the PBOC, dispensed over RMB 100 billion of funds to 21 brokerages to purchase shares of blue-chips as well as small- and medium-sized listed companies through the CSFC. (15) The CSRC also prohibited shareholders with more than $5 \%$ of a listed company's shares from selling off their shares in a six-month time period, among other orders. Also, more than 1,600 of the 2,800 listed companies in Shanghai's and Shenzhen's stock markets were permitted to suspend trading on 8 July, representing $57 \%$ of the total listed companies in China at its height. The vast majority of the trade suspensions had no clear and legitimate reason. ${ }^{(16)}$ In sum, the authorities were trying various means unconventional to global investors in an attempt to prevent China's stock market from sliding indefinitely. The actions taken by policymakers were received by two divergent views. While domestic individual investors earnestly awaited more rescues so that their wealth in the stock market could be retained, some analysts looked at the measures with bewilderment and regarded them as defying market rules. Hong Kong media in general regarded the actions as a "brutal rescue of the stock market" (baoli jiushi 暴力救市).

\section{An unexpected devaluation of the RMB in August amidst China's economic slowdown}

Soon after the stock market rout in June-July, the PBOC unexpectedly announced a new mechanism to adjust the exchange rate of the RMB on 11 August and set the RMB's mid-point at the previous day's closing value. The surprise move by the PBOC triggered a devaluation of the RMB by $1.9 \%$ in one day, the biggest single-day decrease in the yuan's history. (17) Initially, the RMB devaluation was largely interpreted as China's desperate move to revive its slower-than-expected economic growth and proof of the govern- ment's inability to manage the stock market problem. ${ }^{(18)}$ Pessimistic sentiment soon spread among stock markets across the world. On 24 August, stock markets in China, Hong Kong, and other Asian countries experienced massive sell-offs. Subsequently, stock markets in the US and Europe plunged (see Table 1). Referring to the global stock market turbulence, the Chinese and foreign media generally labelled 24 August as "Black Monday."

In the shadow of further yuan devaluation and gloomy prospects for China's economy, the volume of capital flight ${ }^{(19)}$ from China continued at an unprecedented rate. As shown by the decreased volume of foreign reserves the PBOC used to defend the RMB's value, at least US\$42.5 billion and 93.9 billion left China in July and August respectively. ${ }^{(20)}$ The decrease in August was the largest on record. (21) In fact, the capital outflow in this period was not a sudden occurrence but an intensification of capital flight in progress since 2014, when investors started to realise the possibility of China's economic slowdown (see Graph 2). In tandem with other ways to stabilise the yuan, the PBOC has also been actively buying offshore RMB

14. The CSFC was established in October 2011 and is virtually controlled by the CSRC. "Gushi zai zhendang quanqiu zichan chong dingjia" (Turbulence Re-Appeared in the Stock Market, Global Assets Being Re-Valued), Southern Weekly, 27 August 2015, C13.

15. Enoch Yiu, "China Market Regulator and Central Bank Expand Rescue Plan to Stop Panic Selling in Equities," South China Morning Post, 8 October 2015, www.scmp.com/news/china/moneywealth/article/1834437/china-market-regulator-csrc-expands-rescue-plan-stop-panic (accessed on 15 October 2015).

16. "A gu qiguan qian gu ting fu pai"' (Spectacle of A-Share, the Suspension and Resumption of Trading of Thousand Listed Companies), Southern Weekly, 16 July 2015, C15.

17. "The Devaluation of the Yuan:The Battle of Midpoint," The Economist, 15 August 2015, www.economist.com/news/finance-and-economics/21661012-china-initiates-market-reforms-its-currency-then-backtracks-battle (accessed on 18 September 2015).

18. Jamil Anderlini, "China: Credibility on the Line," Financial Times, 28 August 2015, www.ft.com/intl/ cms/s/0/24de9e86-4d76-11e5-9b5d-89a026fda5c9.html\#axzz3n1Axcf00 (accessed on 25 September 2015).

19. Technically, capital cannot freely move across China's border with capital controls in place, so the outflow of capital from China must have been approved by the authorities. However, observers point out that China's capital control mechanism is porous, and investors have learned to move their assets out of China, sidestepping the tough limits set by the authorities. Lingling Wei and Anjani Trivedi, "China Boosts Efforts to Keep Money at Home," The Wall Street Journal, 1 September 2015, www.wsj.com/articles/china-boosts-efforts-to-keep-money-at-home-1441120882 (accessed on 5 September 2015)

20. Lingling Wei and Anjani Trivedi, "China's Forex Reserves Fall by Record \$93.9 Billion on Yuan Intervention," The Wall Street Journal, 7 September 2015, www.wsj.com/articles/china-august-forexreserves-down-by-93-9-billion-as-pboc-intervenes-1441614856 (accessed on 28 September 2015).

21. China Foreign Exchange Reserves, Tradingeconomics, www.tradingeconomics.com/china/foreignexchange-reserves (accessed on 28 September 2015). 


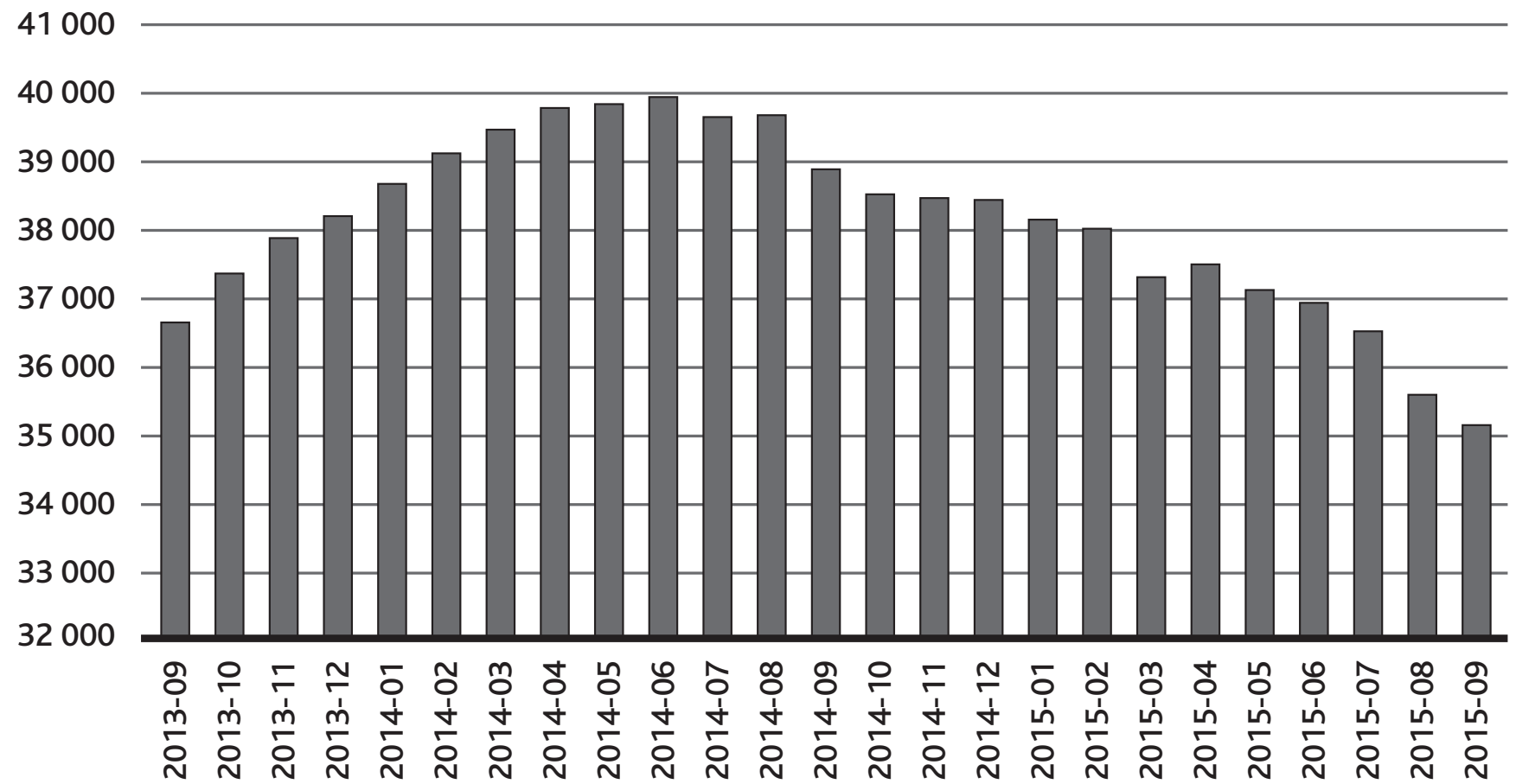

Source: State Administration of Foreign Exchange, www.safe.gov.cn (accessed on 29 October 2015).

to prevent its value from further decline, narrowing the gap between the onshore and offshore currency prices in the second half of September. ${ }^{22}$ On the international level, the $\mathrm{G} 20$ met to discuss how to neutralise the impact of RMB devaluation on the global economy and avoid competitive devaluation. ${ }^{(23)}$ The US Federal Reserve also postponed its plan for an interest rate hike in view of global economic uncertainties. (24)

Showing reservations on the strategies deployed to save the stock market in June-July, policymakers behaved differently this time. They rolled out a number of market-oriented measures to stabilise the market, including lowering the required reserve ratio of the banks as well as reducing the interest rate on 25 August. ${ }^{(25)}$ At the same time, officers under the Ministry of Public Security investigated those who were suspected to be manipulating the market or "spreading rumours" online. Wang Xiaolu 王曉珞, a journalist from the respected financial magazine Caijing 財經, was arrested and put on the television to make a "confession" for his media reporting, which allegedly caused turbulence in the stock market. (26) Officers also combatted underground banks so as to stem illegal cross-border money transfer. ${ }^{(27)}$

\section{The foundation of stock market volatility in China and its impact}

To a certain extent, the characteristics of China's stock market can explain its plunge from mid-June to late-August. First of all, unlike other stock markets dominated by institutional investors, the stock market in China is dominated by small-capital individual investors. With this kind of investor composition, shares can easily be oversold when fears set in. Second, as Professor Dan Luo from the University of Nottingham pointed out, China-listed firms have an "extremely low dividend pay-out rate." Investors tend to bet on an increase in share price instead of the firm's performance in the real economy, and they might rush to sell off shares when prices drop rapidly.
This contributes to market volatility. ${ }^{(28)}$ Third, before the stock market rout in June, it was reported that the stock market was dominated by leveraged credit in search of speculative gains. This has been made possible by poorly regulated "shadow banking" as well as web-based financing firms. "Shadow banking" as an alternative to state-run banks allows people to obtain credit on par with traditional banks, but quicker, easier, and without much regulation, making financial bubbles more easily formed. Moreover, brokers were allowed to lend margin credit to investors to buy shares. By early July, margin credit in the Chinese stock market stood at RMB 2 trillion, four times as much as a year earlier, and accounted for $18 \%$ of the market's free-floating shares, compared with less than $6 \%$ in New York. More importantly, leveraged credit in the stock market actually came from the re-packaging of financial prod-

22. "Offshore Yuan Gains on Intervention Bets before Xi-Obama Summit," Bloomberg, 25 September 2015, www.bloomberg.com/news/articles/2015-09-25/offshore-yuan-gains-on-interventionbets-before-xi-obama-summit (accessed on 20 October 2015).

23. "G20 Binds China to Foreign-Exchange Peace Pact to Contain Mess of 'Burst' Stock-Market Bubble," South China Morning Post, 5 September 2015, www.scmp.com/news/world/ article/1855652/g-20-binds-china-foreign-exchange-peace-pact-post-bubble-cleanup-after (accessed on 15 September 2015).

24. Binyamin Appelbaum, "Fed Leaves Interest Rate Unchanged," New York Times, 17 September 2015, www.nytimes.com/2015/09/18/business/economy/fed-leaves-interest-rates-unchanged.html (accessed on 20 September 2015).

25. Nick Edwards, "China Cuts Interest Rates in Bid to Halt Stock Turmoil and Reassure Markets after 'Black Monday'," South China Morning Post, 25 August 2015, www.scmp.com/news/china/economy/article/1852454/china-cuts-interest-rates-fifth-time-november-new-effort-boost (accessed on 30 August 2015).

26. David Bandurski, "Uneasy Silence Follows Journalist's Arrest," China Media Project, 8 September 2015, http://cmp.hku.hk/2015/09/08/39216 (accessed on 10 September 2015).

27. Lingling Wei and Anjani Trivedi, "China Boosts Efforts to Keep Money at Home," The Wall Street Journal, 1 September 2015, www.wsj.com/articles/china-boosts-efforts-to-keep-money-athome-1441120882 (accessed on 5 September 2015).

28. "Beijing's Policy Flops Don't Spell Doom for China's Real Economy - Just Investor Expectations," China Economic Review, 7 September 2015, www.chinaeconomicreview.com/beijing\%E2\%80 $\% 99 s$-policy-flops-dont-spell-doom-china\%E2\%80\%99s-real-economy\%E2\%80\%94just-investor-expectations (accessed on 10 September 2015). 


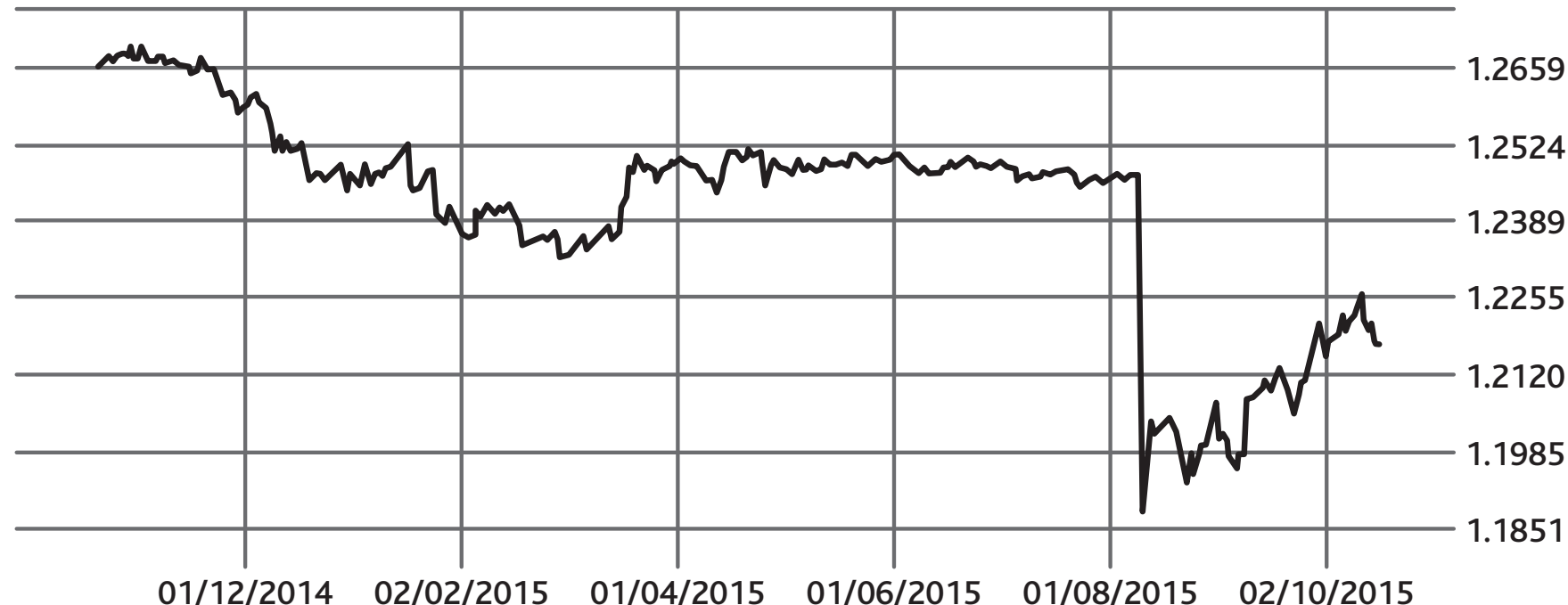

Source: Hang Seng Bank, "Foreign Currency T/T Exchange Rates," https://bank.hangseng.com/1/2/rates/foreign-currency-tt-exchange-rates (accessed on 21 November 2015)

ucts from traditional banks through financial intermediates. The linkage between the banking system and the stock market constitutes a systemic risk that the banking system will suffer if the stock market crashes. If it is true that the CCP has been relying on the banking system to secure its firm grip on political power, the collapse of the banking system could result in dire consequences for the CCP. ${ }^{(29)}$ These analyses are consistent with the official explanation for the need for state intervention. President Xi Jinping 習近平 defended the government's action to intervene in the stock market as necessary and preventive, as he claimed to have contained fear among investors and cushioned systemic risk in the financial sector.

Moreover, although worries over China's economic slowdown have had a huge impact on stock markets, analysts argued that the stock market plunge in late August did not have a great impact on China's real economy. For one thing, the financial market in China is largely detached from the real economy. Historically, the rise and fall of China's stock market capitalisation was not synchronised with the growth or decline of China's GDP. ${ }^{\left({ }^{30}\right)}$ Also, the extent to which private companies or Chinese households utilise the stock market as a way to finance investment or to generate wealth is not significant. Corporate financing through the stock market accounts for only about $5 \%$ of corporate fund-raising in China, while less than $7 \%$ of China's total population participates in the stock market. (31)

\section{Debating the causes of the RMB devaluation}

Since the RMB devaluation there has been speculation over the motive behind it. Some analysts propose that Chinese policymakers used the RMB devaluation as a way to induce export growth and revive its economy as China's economic slowdown has become more evident with poor indices in exports, shipments, ${ }^{(32)}$ and the manufacturing sector. ${ }^{(33)}$ Some other analysts argue, conversely, that the initial scale of RMB devaluation was not large enough to be advantageous to Chinese firms. ${ }^{\left({ }^{4}\right)}$ Also, they point out that continued devaluation of the yuan might backfire on China's economy, as it would put an extra burden on the loan repayment capacity of Chinese enterprises, which recently bear over US\$160 billion of debt. ${ }^{(35)}$ The Chinese Premier Li Keqiang 李 克強 emphasised in early September that it was not their intention to boost export growth by the devaluation, nor did they intend to start a currency war. ${ }^{(36)}$ As the data show, the RMB exchange rate was allowed to fluctuate in both directions after 11 August (see Graph 3).

Other analysts argue that the devaluation was more like a market correction. Dr. Liu Shaojia from Brunel University suggests that the RMB devaluation was an adjustment to the macro-economic situation in China, where the inflation rate was high but the value of the RMB continued growing in the past year. Nicholas R. Lardy, an economist specialising in China's economy, concurred that it was a long overdue market correction. ${ }^{(37)}$ Framing the devaluation saga in this light, analysts tend to believe that the Chinese government is paving the way toward a market-oriented currency exchange mechanism for the yuan. In line with the above analysis, some analysts propose that the reason for the RMB devaluation is to demonstrate China's determination to include the RMB in the IMF's international currency reserve basket of Special Drawing Rights (SDR) (38) by assigning the market a greater role in setting the exchange rate of the RMB before the IMF makes the decision in November 2015. Zhou Xiaochuan 周小川, the Governor of the PBOC, in April publicly

29. Patrick Hess, "China's Financial System: Past Reforms, Future Ambitions and Current State," art. cit., pp. 32-33.

30. Barry Naughton, The Chinese Economy: Transitions and Growth, op. cit., p. 468.

31. Scott Cendrowski, "Here's What You May Not Know about the Chinese Stock Market," Fortune, 2 September 2015, http://fortune.com/2015/09/02/heres-what-you-may-not-know-about-thechinese-stock-market (accessed on 4 September 2015).

32. Richard Macauley, "China Has Unexpectedly Devalued its Currency in an Attempt to Boost Exports and Revive its Economy," Quartz, 11 August 2015, http://qz.com/476659/china-has-devaluedits-currency-by-the-most-in-over-20-years (accessed on 1 September 2015).

33. William Kazer, "China Factory Gauge Slips to Three-Year Low in August," The Wall Street Journal, 1 September 2015, www.wsj.com/articles/china-august-manufacturing-pmi-slips-1441070881 (accessed on 14 September 2015).

34. "The Devaluation of the Yuan: The Battle of Midpoint," art. cit.

35. Peter Evais, "China's Renminbi Devaluation May Initiate New Phase in Global Currency War," The New York Times, 14 August 2015, http://cn.nytimes.com/business/20150814/c14db-currency/enus (accessed on 16 September 2015).

36. "Li Keqiang cheng guzai hou cuoshi fang xitong fengxian" (Premier Li Keqiang Seeks to Prevent Systemic Risk After the Stock Market Crisis), Cable TV, 10 September 2015, http://cablenews.icable.com/webapps/news_video/index.php?news_id=465962 (accessed on 10 September 2015).

37. Nicholas Lardy, "False Alarm on a Crisis in China," The New York Times, 26 August 2015, www.nytimes.com/2015/08/26/opinion/false-alarm-on-a-crisis-in-china.html (accessed on 2 September 2015).

38. The Special Drawing Rights are foreign exchange reserve assets of the IMF, the value of which is determined by a basket of currencies including the US dollar, Euro, UK pound, and Japanese yen as of now. 
associated the capital account opening with China's bid for the RMB's inclusion in the SDR. ${ }^{(39)}$ After the RMB devaluation on 11 August, the IMF also endorsed it as a step toward market-oriented reform. ${ }^{(40)}$

\section{Market-oriented currency reform: Rhetorical or substantial?}

In 2012, the Chinese government announced the $12^{\text {th }} 5$-year Guidance for the Development and Reform of the Financial Industry (jinrongye fazhan he gaige "shi er wu" guihua 金融業發展和改革“十二五”規劃), which stressed its main direction as assigning a greater role to the market in deciding the exchange rate, to further open the capital account, and to diversify foreign reserves. ${ }^{(41)}$ However, Arthur R. Kroeber, Senior Fellow of Foreign Policy at the Brookings-Tsinghua Center, pointed out that while the CCP asserted it would give the market a "decisive role" in financial reform, the Party is also prepared to maintain the "dominant role" of the state sector. ${ }^{(42)}$ If the ultimate objective of all economic reforms since Deng Xiaoping has always been to maintain the political power of the CCP, ${ }^{(43)}$ how much the CCP would loosen its grip on economic control in exchange for the benefits of obeying market rules remains a big question in financial reform. It may well depend on the personal attitude of President Xi, who has taken leadership of the two CCP groups overseeing economic policies, namely the Central Leading Group for Financial and Economic Affairs (zhongyang caijing lingdao xiaozu 中央財經領導小組) and the Central Leading Group for Comprehensively Deepening Reforms (zhongyang quanmian shenhua gaige lingdao xiaozu 中央全面深化改革領導小組).

RMB internationalisation is certainly a catalyst for China's currency reform. To achieve this policy goal, scholars point out that a market-oriented exchange rate, opening of the capital account, and a freely convertible RMB are important prerequisites. ${ }^{(44)}$ In the process, the Chinese government must confront the trilemma of international monetary policy, where the independence to dictate domestic interest rates (independent monetary policy), the free flow of capital (opening of the capital account), and currency stability (fixed exchange rate) cannot be achieved at the same time. A country can at best achieve only two of the three policy outcomes at one time. Over the past decades, the trilemma has been overshadowed by the continued net inflow of foreign capital into China and the PBOC's ability to absorb the inflow by increasing foreign reserves. The situation has changed in recent years, however, when China's economic slowdown has been accompanied by capital outflow. ${ }^{(45)}$ If China is determined to press ahead with a market-oriented exchange rate regime for the sake of the RMB's inclusion in the SDR in the short run and its internationalisation in the long run, the gradual opening of the capital account and exposing the PBOC to the monetary trilemma is inevitable. ${ }^{(46)}$ While China rolled out measures conducive to market-oriented currency reform before and after the RMB devaluation, there are signs that the state would not shy away when necessary. Yam Chi-kong 任志剛, the former Chief Executive of the Hong Kong Monetary Authority, has insisted in a paper on the need for capital control even if the RMB should become fully convertible. ${ }^{(47)}$ In April, PBOC Governor Zhou argued that China would not pursue a freely or fully convertible RMB regime but rather a managed convertible one in order to maintain the currency's value and safe financial environment. ${ }^{(48)}$

\section{Conclusion}

In retrospect, the RMB devaluation seems more a part of the RMB internationalisation process than an arbitrary move to rescue China's economic slowdown. As a country with the world's second largest economy, China needs to pay much more attention to policy communication with the world of investors as a lesson learnt from the RMB devaluation saga in August. The majority of critics attributed the global market turbulence in August to communication problems on the part of Chinese policymakers. ${ }^{(49)}$ Moreover, the stock market since mid-2015 is in need of deeper reform if the Chinese government wants to establish a financial market alternative to bank loans for investment and be better equipped to provide direct financing to SOEs or private corporations. This would build a financial market that contributes to the prosperity of the real economy instead of having one speculative in nature.

Under the policy goal of internationalising the yuan, whether China can successfully pursue a market-oriented exchange rate regime while achieving managed capital flow and monetary policy independence at the same time remains to be seen. What is certain is that China's financial reform in general, and currency reform in particular, will continue. Yet, given the role of the financial sector in the CCP's political power, and the sensitivity of foreign-local financial connections as perceived by the CCP, the end product of financial reform may take a form unfamiliar to Western counterparts. After all, besides sustainable economic prosperity, other concerns such as political legitimacy, social stability, and the CCP's monopolistic rule are all essential to China's leaders in the pursuit of "capitalism with Chinese characteristics." (50)

\section{Anthony H. F. Li is a research assistant at the CEFC (anthonylihf@gmail.com).}

CEFC News Analysis is compiled from the CEFC's fortnightly selection of Press Highlights, available at www.cefc.com.hk.

39. "Quanmian ziyou duihuan lu yao" (A Long Way to Go Before RMB's Totally Free Conversion), Hong Kong Economic Journal, 20 July 2015.

40. Keith Bradsher, "China's Devaluation of the Its Currency Was a Call to Action," The New York Times, 18 August 2015, http://cn.nytimes.com/business/20150818/c18chinaecon/en-us (accessed on 12 September 2015).

41. Patrick Hess, "China's Financial System: Past Reforms, Future Ambitions and Current State," art. cit., p. 37.

42. Arthur R. Kroeber, "Making Sense of China's Stock Market Mess," Brookings, 13 July 2015, www.brookings.edu/research/opinions/2015/07/13-china-stock-market-kroeber (accessed on 21 September 2015)

43. Patrick Hess, "China's Financial System: Past Reforms, Future Ambitions and Current State," art. cit., p. 23.

44. Yung Chul Park, "RMB Internationalization and Its Implications for Financial and Monetary Cooperation in East Asia," China and World Economy, Vol. 18, No. 2, 2010, pp. 1-21.

45. "Beijing Faces Up to its Monetary Trilemma," Financial Times, 7 September 2015, www.ft.com/cms/s/0/a8c9b500-555a-11e5-a28b-50226830d644.html\#axzz3n1Axcf00 (accessed on 26 September 2015).

46. Duncan Weldon, "China's Impossible Trinity," BBC, 8 September 2015, www.bbc.com/news/business-34178247 (accessed on 26 September 2015).

47. Chi-kong Yam, "Rang renminbi ke duihuan wentuo de banfa" (A Safe Approach to Convertibility for the Renminbi), Thematic Study No. 5, Institute of Clobal Economics and Finance, The Chinese University of Hong Kong, April 2011.

48. Xiaochuan Zhou, "Statement by the Honorable Zhou Xiaochuan Governor of the IMF for China to the Thirty-First Meeting of the International Monetary and Financial Committee Washington, D.C.," 18 April 2015, p. 6.

49. Jamil Anderlini, "China: Credibility on the Line," art. cit;;"Beijing's Policy Flops Don't Spell Doom for China's Real Economy," art. cit:; Koichi Hamada, "China's Political Interventions," Project Syndicate, 28 August 2015, www.project-syndicate.org/commentary/chinese-market-interventionby-koichi-hamada-2015-08\#dgMjM5XwXib31wzF.99 (accessed on 28 September, 2015).

50. Patrick Hess, "China's Financial System: Past Reforms, Future Ambitions and Current State," art. cit., p. 23. 